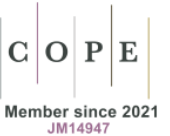

JM14947
Multicultural Shakespeare:

Translation, Appropriation and Performance vol. 23 (38), 2021

https://doi.org/10.18778/2083-8530.23.04

Arup K. Chatterjee* (1)

\title{
Performing Calibanesque Baptisms: Shakespearean Fractals of British Indian History
}

\begin{abstract}
This paper uncovers new complexity for Shakespearean studies in examining three anecdotes overlooked in related historiography - the first Indian baptism in Britain, that of Peter Pope, in 1616, and its extrapolation in Victorian history as Calibanesque; the tale of Catherine Bengall, an Indian servant baptised in 1745 in London and left to bear an illegitimate child, before vanishing from Company records (like Virginia Woolf's invention Judith Shakespeare vanishing in Shakespeare's London); and the forgotten John Talbot Shakespear, a Company official in early nineteenth-century Bengal and descendant of William Shakespeare. I argue that the anecdotal links between Peter, Caliban, Catherine, Judith, Shakespear and Shakespeare should be seen as Jungian effects of non-causal "synchronic" reality or on lines of Benoit Mandelbrot's conception of fractals (rough and self-regulating geometries of natural microforms). Although anecdotes and historemes get incorporated into historical establishmentarianism, seeing history in a framework of fractals fundamentally resists such appropriations. This poses new challenges for Shakespearean historiography, while underscoring distinctions between Shakespeareanism (sociological epiphenomena) and Shakespeare (the man himself).
\end{abstract}

Keywords: Shakespeare, Caliban, Peter Pope, Catherine Bengall, John Talbot Shakespeare, genealogy, New Historicism, anecdotes, fractals, London

In the year of William Shakespeare's death, another momentous event occurred in London. On December 22, 1616, Peter Pope, the first Indian to be baptised in Britain, walked up to St Dionis at Fenchurch Street. The ceremony of his spiritual rebirth under the Anglican Church was attended by the Lord Mayor, members of the Privy Council and the newly formed East India Company, blessed by the Archbishop of Canterbury, and monitored, in proxy, by King James himself, who had chosen the new name for the sixteen-year-old Indian lad from "Bengala". Around 1800, a seemingly unconnected episode occurred in Calcutta with the arrival of John Talbot Shakespear, a descendant of William Shakespeare, whom almost no one recognised for that illustrious genealogy.

* OP Jindal Global University, India. 
He married the daughter of William Makepeace Thackeray senior, grandfather of the more famous novelist. John Talbot Shakespear died in 1825. His forgotten and weatherworn tombstone lies in Calcutta's Park Street Cemetery. Another anecdote, lying chronologically between the histories of Peter and Shakespear, is that of Catherine Bengall. She was trafficked from Bengal to London, baptised in the summer of 1745 at St James Church in Westminster, impregnated by one William Lloyd, left impoverished and with child, given asylum in the workhouse of St Martin in the Fields, only to disappear from the records of the East India Company by the following year.

The above events were entirely overshadowed in Britain by those of national importance - the English Civil War, the beheading of King Charles I, the Restoration of monarchy, the Great Fire of London, the expansion of tea, silk, opium and gunpowder trade between Britain and South Asia, the Battles of Plassey and Buxar, the popularity of Shakespeare's plays in colonial Bengal and two centuries of India's colonisation. This paper demonstrates how, if the anecdotes of Peter Pope, John Talbot Shakespear and Catherine Bengall had stayed alive in popular histories, Shakespearean studies would have been enriched.

\section{Historemes and fractals}

While hearing the persuasions of Shakespearean scholars Sigurd Burckhardt and Stephen Greenblatt, voices of the dead seem to contrive themselves as the words of the living; that the many meanings of Shakespeareanism were and remain, after all, works of social will and discourse. Are the lost stories of Peter, Catherine and John Talbot - unravelled by Victorian historiography and again thrust into oblivion - also outcomes of social determinism?

Victorians recognised that Peter's baptism reflected an inherent racialism in British attitudes that prefigured in the treatment meted out to Caliban in Shakespeare's allegedly final play, The Tempest (1611). On the other hand, with William Makepeace Thackeray as his nephew, the life and extended family of John Talbot Shakespear were as eventful as a theatrical assemblage of Shakespearean twists. Finally, when Virginia Woolf wrote A Room of One's Own (1929), she created Shakespeare's fictional sister, Judith, who, probably without the knowledge of the author, uncannily resembled Catherine. These correlations are not suggestions that Shakespeare had foreseen Peter's baptism, that Woolf's feminism was inspired by an anecdote from Britain's exploitative imperial history, or that there was any secret literary connection between the works of William Makepeace Thackeray and, his Elizabethan namesake, William Shakespeare. Recalling these forgotten anecdotes uncovers new complexity in our notions of history, especially Shakespearean historiography, 
and what relationship anecdotes share with grand historical discourses. Each of these anecdotes is famously linked to literature, being such stuff as new historiography may be built on. Like the anecdotes of Peter, Shakespear and Catherine, the concept of anecdote itself has been marginalised by vociferous imperial, nationalist and identitarian histories. In 1983, Marc Ferro called the "fortuitous incident", repressed by churches, states, educational institutions and even society, "a privileged historical object" bearing the seeds of disruption (qtd. in Gossman 168). Six years later, New Historicist Joel Fineman took a remarkable shot at quantising history, to extract the "smallest minimal unit of the historiographic fact", the historeme. Fineman reckoned that the historeme "lets history happen by virtue of the way it introduces an opening into the teleological, and therefore timeless, narration of beginning, middle and end." The historeme disrupts the realism, teleology and causality of history by staging itself as an abject historical truth. It establishes "an event as an event within and yet without" historical successions (Fineman 57-61).

In The Archaeology of Knowledge (1969), Michel Foucault attempted something similar in what he called "tangential" or outlier histories, a history "not of literature but of that tangential rumour, that everyday, transient writing that never acquires the status of an oeuvre, or is immediately lost: the analysis of sub-literatures, almanacs, reviews and newspapers, temporary successes, anonymous authors" (153). This raises fundamental questions on historiography and literariness. That the literary and the historiographical are assumed to be phylogenetically different is a tragic-though real-manifestation of our alienation from what Greenblatt called the order of things. Order "is never simply a given: it takes labour to produce, sustain, reproduce, and transmit the way things are, and this labour may be withheld or transformed" (Greenblatt, 1990: 165).

New Historicism, according to Greenblatt, is to read the traces of the past with due consideration otherwise reserved for literary texts. Hayden White urges us to see the overlooked essence of historiography in aspects like emergence, contingency, the anecdotal and the abject (63-64). Otherwise, an author runs the gauntlet of being determined as the sole cause and effect of his writings - as in the phrase I know my Shakespeare - and trivialised into personality assassination. Although historians have invested decades in problematising the authorship of Shakespeare's plays - some now credited to Christopher Marlowe and others - the bard gets attacked for racialist and imperialist stances of an author rather than being seen as epiphenomena of social discourse. A case in point is Burckhardt's note on the supreme importance of anachronism in Julius Caesar. Set in ancient Rome, the play is criticised by modern day University wits for having the modern invention of a clock as an implied prop, as though Shakespeare's lack of university education - supposedly there were no clocks in ancient Rome-caused this blooper. Counterintuitively, 
Burckhardt argues that Shakespeare speaks to us as clearly as to Elizabethans, inspiring our willing suspension of disbelief, while the plays of his university educated contemporaries, fastidious and footnoted, have dropped dead (4-11).

The hallmark of poststructuralist thinking is its sustained onslaught on macrocosmic sociological constructs by quantising fundamental building blocks of reality like perception, cognition and meaning. Poststructuralists have done to our consciousness of history what theories of relativity and quantum mechanics did to classical Newtonian physics. The poststructuralist oeuvre, then, is to defy the knowability of history and the authenticity of historical meanings. In Victorian historiography, considerable attention was paid to publishing anecdotes, with publishers increasingly desirous of appeasing readers who were "allegedly no longer willing or able to engage seriously with literature or history" (Gossman 154). However, this itself does not answer the question: are anecdotes formally and functionally disconnected from the vectors of historical time, or can their invocation fundamentally alter perceptions of history-in this case the history that informs interpretations of Shakespeare and his reception in colonial India? By way of exploring possible answers, this paper serves a twofold purpose.

First is to propose a new paradigm in social sciences for viewing historical anecdotes as fractals. Deeply canonised histories, such as Shakespeare and the British imperial history of India, have resisted New Historicism. In India, Shakespearean interpretations are increasingly shaped under immediate postcolonial realities and identitarian politics which do not necessarily allow for nuanced New Historicist readings. Though this is inevitable for Shakespearean studies, it runs the risk of systematically omitting anecdotal subversions of historiography from within the framework of a time past. Meanwhile, although there is nothing fundamentally erroneous in defining smallest units of historiographical facts as historemes - it is rather poetical and evocative-one operational hazard is that it makes historiography less interdisciplinary, perhaps alienating psychology (from which New Historicism derives a lot) or quantum studies (an emergent discipline cutting across physics, biology, statistics, computing, economics and geography) which can not only mainstream but also enrich New Historicism.

My formal purpose is to study anecdotal fractals around Pope, Bengall and Shakespear, examining their subversions of Shakespearean historiography, and how they contribute from margins as more than marginalia in restructuring the background. Carl Jung, the chief exponent of the collective unconscious - a pseudoscientific concept in psychology with increasing neuroscientific validity today-proposed that though reality is perceived as continuous and causal, manifold events also unfold as non-causal and synchronic, and yet appear as coincidental and continuous. Later, Benoit Mandelbrot transformed mathematics, physics and geography by demonstrating fractals as the essential 
rough and self-governing geometry of microforms, otherwise perceived as smooth, such as in coastlines, plant life, neuronal forms, molecular patters or even the randomness of financial markets. Jung's notion of synchronicity and Mandelbrot's fractals can broaden explanations of the historiographical importance of anecdotes, besides strengthening the bond between natural sciences and humanities. I argue that while the microhistories of Pope, Bengall and Shakespear are satisfying as anecdotes or as standalone historemes, like synchronic fractals, they are also the self-governing building blocks of British and Indian historiography. As the non-causal, fractalized and rough microstructural elements in a smooth-looking macrostructure, they dispute both colonial and postcolonial structures of macro-historiography revolving Shakespeare.

\section{Dreaming of Caliban}

Edward Duffield Neill-American Presbyterian and Chancellor of the University of Minnesota - may appear as the most unlikely candidate to unearth the story of Peter's baptism. But, the source of his book, described in its title, Memoir of Rev. Patrick Copland: Rector Elect of the First Projected College in the United States: A Chapter of the English Colonisation of America (1871), does explain. Peter Pope figures in Neill's history as a postcolonial fractal - postcolonial in the sense that America was an erstwhile British colony.

For centuries Fenchurch Street has, during Christmas week, been alive with persons busily passing to and fro, but on Sunday, $22^{\text {nd }}$ of December 1616, an unusual crowd surged toward the Church of St Dennis, for it had been announced that, by the rite of baptism, a lad, a native of Bengala, was to be initiated into the Church of Christ (Neill, 1871: 12).

Despite the climactic representation of the pageant, Neill must have had little idea of its future significance. He saw Peter as a "great rarity in the streets of London during the reign of James the First; and as he walked, the women with curiosity, peeped through cracks of the front doors, and children went before, and followed his steps, their mouths agape with astonishment" (Neill, 1871: 12). Peter's arrival in London was consistent with the demographics of Tudor times. With more deaths than births in England, ranks of tailors, gun-makers, dyers, weavers, needle-manufacturers and labourers came to be constituted by the French, Dutch, Danish, North Africans and even Indians (Ackroyd 96). Peter was brought over by Patrick Copland, the East India Company's Chaplain at Masulipatam. In a slightly altered version, Peter was first brought to London by one Captain Best and left in the care of Copland, around 1614, for the boy to be 
"taught and instructed in religion, that hereafter he might upon occasion be sent unto his country, where God may be pleased to make him an instrument in converting some of his nation" (Neill, 1984: 375).

In either case, Peter was in "the heart of Britannia as a prospective cavea porcellus to test the effects of the fruits of its civilisation" (Chatterjee, 2021: 91). Under Copland's training, he learned to "to speake, to reade and write the English tongue and hand, both Romane and Secretary, within less than the space of a yeare" (Copland 29). In early 1615, Copland approached the Company for Peter's baptism to cultivate him as one of the "first-fruits of India" (Neill, 1871: 11). Neill was prompt to make the connection between Peter and Caliban. "Dead or alive?" asks Trinculo, looking at Shakespeare's savage, in The Tempest. "A fish. He smells like a fish, a very ancient and fish-like smell, a kind of not-ofthe-newest poor-john. A strange fish!" Without necessarily dehumanising Peter, Neill quotes this passage, describing the response of an Elizabethan crowd to an alien Asiatic. Tellingly, the subaltern in this story can not only not speak but also be not named except as a metaphor. Upon seeing Caliban in Prospero's island, Trinculo determines that if he was in England, no man would shy away from giving "a piece of silver" just to have a glimpse of this "strange beast" or "dead Indian" (Shakespeare 34). Peter too, in one manner of speaking, was a dead Indian, reborn as Anglican. His Anglican name was not his own. If we assume his baptism was carried with his best spiritual interests in the Company's heart - though contemporary historians can hardly be persuaded to-his Christianised name was a metaphor or vehicle in service of the Church. Even if we assume that the Church was a benevolent institution in his life, we find him called in subhuman metaphors - fruit or fish - but certainly not endearments.

Fractals of Peter's life begin and end pretty much at Fenchurch Street. He stayed on in London for a year, following which he returned to India with Copland, in 1617, aboard the ship Royal James, fortuitously named after his own name-giver. Copland came back to England in 1621, before preaching at the Virginia Council where he delivered the sermon Virginia's God Be Thanked. This became the original source for Peter's story. Copland showed the Council the letters written by Peter in Latin and English. Addressed to Sir Thomas Smith (a Company Governor) and Martin Pring (commander of the Royal James), and written between 1619 and 1620, the letters were indubitable signs of the first roots of English colonial education in an Indian mind. Equally indubitably, Peter's baptism appears as an early experiment of British imperialism in its backyard, less than a mile from Leadenhall Street, where, on September 24, 1599, twenty-four British merchants had gathered in a decrepit building to form the East India Company to compete against Dutch, Spanish and Portuguese privateers. Unsurprisingly, Indian New Historicism has tried interpreting the dreamy imagery of an Indian boy "stol'n from an Indian King" and the "spiced Indian air by night" in A Midsummer Night's Dream as allegories of British 
trade with Malabar and Bengal, where Ralph Fitch - the first recorded Englishman in India-visited in the 1580s (Desai 141-48). The allegorical reading has not gone unchallenged, since almost all Indian references in Shakespeare are stereotypically racialist and gendered, although the unexceptional "exotic" and "undifferentiated" otherness of India, therein, transcends Eurocentric aesthetic hegemonies (Chaudhuri, 2005). But how do we interpret Peter's role in it?

Peter was a docile subject of a future Empire, willingly tutored in the imperial languages, Latin and English. The disruptive element comes in his comparison with Caliban, a character known for swearing in the white man's tongue, one who lives a deeply schizophrenic life in Shakespearean criticism, beginning as a sign of evil oppression and going on to be the posterchild of postcolonial, anticolonial and antiracial subjectivities. In Neill's sketch, Peter's baptism in London mimics Caliban's abjection in Prospero's island. Peter could have been a legendary symbol for marginalised voices under colonial rule; but he was not to be. Instead of asking what historical knowledge we can really glean from Peter's episode, we should ask what can historical knowledge glean from it, besides asking, what psychological associations reminded Neill of The Tempest and Caliban while reconstructing Peter's anecdote.

\section{Shakespeare's sister and Shakespeare's descendant}

Way back in March 1550, one Salamon Nurr (conjec. Suleman Noor) was interred at St Margaret's in Westminster. On December 28, 1613, one Samuel Munsur, a "blackamour", married a Jane Johnson at St Nicholas Church, in Deptford, less than five miles from Shakespeare's Globe. More than fifteen Indian burials, baptisms or marriages in London populate the Company's seventeenth-century records. As told by Patrick Copland in the title page of his book Virginia's God be Thanked (1622), even in his time, Peter's baptism was considered to have been held "in a famous assembly." But the evangelism of the Company would soon be overshadowed by the traffic of Indian lascars, servants and even slaves. Eighteenth-century diplomat and diarist William Hickey brought over his servant William Munnew, from Calcutta. In 1737, a "Black" Indian boy, Pompey, was brought from Bengal by Captain Benfield and kept as a slave by Major Woodford of the Virginia Company. Even in Victorian London, the Countess of Londesborough of Mayfair bought an Indian servant called Bimbi. She dressed him in motley costumes and a pink turban, forcing him to dance before her guests.

In 1720, a sixteen-year-old Indian lad, stolen from his family in Madras and brought to London by Captain Dawes, was given to Elizabeth Turner and rechristened as "Julian". He ran away on August 8, 1724, after stealing 
20 guineas and setting the house on fire. After being arrested, Julian confessed to his crime, pleading, however, that he had been tortured for several years and forced to provide Calibanesque entertainment. Mrs Turner's refutation of these allegations was given more credence than her servant, and Julian was publicly hanged at Tyburn, although not before he was baptised as "John". In 1795, the spring issue of the Morning Chronicle published the report of Hyder, a fourteenyear-old Bengali servant employed by Mrs Ramus of 58 Baker Street, Portman Square. He too had stolen items from his lady's boudoir. Unlike Julian, he was spared hanging. It was not uncommon to wake up in eighteenth-century London to the news of runaway Indian servants, such as: "a Slender middle-sized India Black, in a dark grey Livery with Brass Buttons", fled from Mrs Thwaits home in Stepney (Taylor 159). And it was commonplace knowledge that Indian servants and slaves haunted the upscale neighbourhoods of Hampstead, Highgate, Tottenham, Tooting, Stepney, Marylebone, Whitechapel, Essex, Greenwich or Lewisham.

Virginia Woolf's fictional creation of Judith-William Shakespeare's sister - in A Room of One's Own (1929), may not have relied on many historical records other than Professor Trevelyan's History of England (1926), but was an uncanny recapitulation of the story of an Indian servant girl lost in London. Woolf's story went thus. Like William Shakespeare, Judith was "extraordinarily talented and gifted", though unrecognised. Judith travelled to London from Stratford upon Avon and, in her teens, she became the mistress of the actormanager Nick Greene, mothering his child, forced into anonymity, destitution and finally "buried at some cross-roads where the omnibuses now stop outside the Elephant and Castle" (Woolf 71-73). Judith's fictional life points to a deep sociological tragedy-gender, class and religious hierarchies pitted against the artistic development of the spirit of genius. Catherine Bengall's anecdote singularly reinforces Woolf's invention, but only to ultimately challenge it. Catherine reached London in the 1740s, being purchased at the age of ten in Bengal by Suthern Davies and presented to Ann Suthern. She was baptised on November 26, 1745, at St James Church in Westminster. Unexpectedly freed by the Sutherns, Catherine's life imitated Judith's, as she became the mistress of one William Lloyd. In September 1746, she gave birth to a son at the parish workhouse of St Martin in the Fields. He was named William after his father - coincidentally the namesake of Judith's famous brother - before both mother and son vanished from the registers of the Company, like Judith herself had in the previous century. Catherine's unfinished tale compels us to surmise that for every Judith, who was a victim of gender oppression, there must also have been a Mrs Turner, propagating racial and class hierarchies, as witnessed in the large number of reports of runaway Indian servants. Hidden behind the backdrop to gender hierarchies in Shakespearean England were informal and formal systems of slave trade between Europe and the East. 
Turning to India, we find that though Shakespeare's plays had developed a niche by the second half of the eighteenth century, his life was not necessarily well known. Following Dr Samuel Johnson's The Plays of William Shakespeare (1765) - an early watershed in the canon of Shakespearean studies - the bard's posthumous life ran parallel to the colonisation of India. The eighteenth-century British administration in India was more in tune with William Jones' philology and Orientalist outlook, which involved rapaciously translating Arabic, Persian and Sanskrit texts into English. When Jones called Kalidasa "the Shakespeare of India," after translating Abhijnan Shakuntalam in 1789 , it was arguably a mutual elevation of both poets. Much less known is the fact that, in Calcutta's South Park Street cemetery, Jones and many other unremembered Orientalists and Britons from the time lie buried beside two Shakespear tombs, one of which is of John Talbot Shakespear, the forgotten descendant of William Shakespeare. Born to John and Mary Shakespear in 1783, John Talbot arrived in India from England as a low-ranking East India Company official in Calcutta, in the early 1800s. He married Emily Amelia Thackeray - the eldest daughter of William Makepeace Thackeray, a British collector who made his fortune trading elephants and ivory from Sylhet. After retiring in 1776, Thackeray was so rich that, for at least three generations, no one in his family needed to work. He had even sued the East India Company for $£ 3,700$ - about $£ .7$ million today — over the death of his smuggled elephants.

Compared to the Thackerays, John Talbot Shakespear is of very marginal interest today, if at all, and only for antiquarian reasons. His literary lineage had little or no bearing on his career. We cannot ascertain if his Shakespearean lineage even mattered to the East India Company. Shakespear's link to the bard of Avon was first established by the Victorian antiquarian, George Russel French, in his book Shakspeareana Genealogica (1869), and reaffirmed in Charlotte Carmichael Stopes' Shakspeare's Family (1901). According to French, John Talbot's line branched out of the Shakespears of Stepney (or Shadwell), who probably descended from Gilbert or Thomas Shakespeare, the bard's brother and uncle, respectively. French acquired the genealogical details from John Talbot's nephew, Lieutenant Colonel John Davenport Shakespear. A crucial evidence linking Shakespeare and Shakespear was the artefact in the possession of John Davenport: "a drawing on a parchment of a coat of arms, pronounced by an eminent herald ... more than 200 years old, which is precisely the same ... as the coat of arms granted to the Poet's father in 1596" (French 546).

The sixth son of Thackeray the senior, Rev Francis Thackeray, married Shakespear's sister, Marianne. Francis' elder brother and secretary to the Board of Revenue, Richmond Thackeray, married Anne Becher of Bath. Anne had been falsely informed by her grandmother that her fiancé, Lieutenant Henry Carmichael-Smyth, had died of a lingering fever. Had Anne not been thus 
deceived, her son William Makepeace Thackeray_-born in 1811 at Thackeray House in Calcutta's Alipore-may have never stepped into literary society, or indeed the mortal world. Then, a dramatic irony followed. While Anne's lover was very much alive back in England, her husband died of lingering fever in 1815, and was buried at the North Park Street Cemetery. Richmond was a patron to John Talbot, having appointed him as assistant collector in Birbhum. The deceased Richmond's name inspired the name of John Talbot and Emily Shakespear's youngest son, Sir Richmond Campbell Shakespear, who later became an agent to the Governor General of Central India and was awarded Companion of the Bath in 1860. John Talbot's second son was named William Makepeace Shakespear after the child's maternal grandfather and the most famous William in John Talbot's lineage, William Shakespeare himself. After a quiet career, John Talbot Shakespear died by drowning in 1825, during a voyage to Cape Town, within a year of his wife's death due to a fever she had contracted in the Calcutta summer.

The memory of the line of John Talbot and Emily Shakespear-the Indian branch of Shakespeares-was overshadowed by larger discourses of imperialism until, in 2014, when, British and Indian newspapers euphorically reported that British Prime Minister David Cameron was the great great grandson of John Talbot Shakespear.

\section{Fractalising the Shakespearean legacy}

John Talbot Shakespear's oblivion implicates the elites of British Calcutta, who were more interested in building a commercial enterprise than in Shakespearean genealogy or literature. In 1807, Charles Lamb, who wanted to have his name talked of in China and the East, together with his sister Mary Lamb, published the Tales from Shakespeare, which played a major role in disseminating Shakespeare in the Orient (Dai 2019). Even prior to Lamb, Shakespeare's plays were well known in eighteenth-century Bengal. Before the Battle of Plassey, British delegates had built a playhouse in Calcutta, in 1753. The Calcutta Theatre came up in 1775 and ran for three decades. By the 1780s, Bengal was exposed to a new culture of periodicals, with The Bengal Gazette and The Indian Gazette carrying theatre reviews, which included the performances of Hamlet, Romeo and Juliet, The Merchant of Venice and Richard III. And, then, in November 1813, the famous Chowringhee Theatre was founded (Dahiya 2018).

Calcutta's Hindu College, established in 1817, which later became the Presidency College, also marked a turning point in Shakespearean performances in British India. A growing bourgeois intelligentsia - pioneered by the young poet Henry Louis Vivian Derozio - took to reviewing, editing, translating and propagating Shakespearean theatre in Bengal. Around the time of Macaulay's 
infamous minute and the English Education Act of 1835, missionaries and Company officials realised the importance of a secular English studies curriculum in India, which could be spearheaded by Shakespeare owing to the implicit streak of Protestant ideals in his works (Viswanathan 80-81). The theatre of Bengali Renaissance derived immensely from Shakespeare's plays as theatre exponents like Michael Madhusudhan Dutta, Girish Chandra Ghosh, Haralal Ray Ardhendu Shekar Mustafi, Amar Datta, Sisir Kumar Bhaduri and Ahindra Chaudh went on adapting Shakespeare into Bengali. Indian Shakespeareanism was a deeply heterogeneous and mimetic phenomenon, reflecting larger discourses of British imperialism and bourgeois Indian nationalism in Victorian and Edwardian times (Bhattacharyya, 1964; Chatterjee, 1995; Sarkar, 2016; Marcus, 2017). Although Shakespeareanism began as a colonising and civilising mission in India, Shakespearean hybridity fostered a new Bengali sense of cultural and national identity which could muzzle the hegemony of British aesthetic sensibilities, the binary of tradition versus modernity, and the colonial falsehood of India's cultural inferiority (Singh 139-146).

Seen in a postcolonial framework, Shakespearean appropriations in colonial India were bound to overshadow the importance of John Talbot Shakespear. Even in his lifetime, John Talbot was surrounded by the more powerful Thackerays, who had much firmer grip over imperial matters and Victorian literary tastes. Shakespeare's genealogy was not altogether unknown to Victorian England, given the stature of French, who had earlier written commanding ancestries of Queen Victoria and Prince Albert, and that of Nelson and Wellington beginning from King Edward I. Neill, whom we must thank for Peter's anecdote, was also an influential scholar, having authored over ten volumes of ecclesiastical histories. In recent times, Peter Pope's baptism and Catherine Bengall's disappearance have become the subjects of historical inquiry, if only in a miniscule capacity compared to the kind of critical attention that British generals, Indian nationalism or Shakespearean theatre have enjoyed (Visram, 2002; Fisher, 2006; Habib, 2008). If we ask, why the anecdotes of Peter, Catherine and Shakespear are abject outliers in this history, the obvious answer is that they are the casualties of a bifurcated historicisation of Shakespeare. On the one hand was the cultural hegemony that the Company wanted to secure in colonial Calcutta. On the other, is the combine of anticolonial and New Historicist historiographies that have joined forces since the 1980s (Parvini, 2017). Besides Neill's appropriation of the Calibanesque in recording Peter's baptism, the racialist discourse of Caliban being the evolutionary missing link between primitive apes and homo sapiens also thrived in Victorian England (Wilson, 1873). Taking The Tempest to illustrate the Shakespeare debates of the last fort years, we find that despite celebrations of Shakespeare and Prospero as master designers and architects (Comito, 1981), there have been sustained New Historicist attacks on Shakespeareanism for 
peddling Renaissance prototypes of imperialist ideologies and godlike attributes of the imperial ruler (Brown, 1985; Flagstad, 1986; Skura, 1989).

There has been painstaking historiography on the evolution of the meanings and attributes of Calibanesque, which emerged in Victorian times as the name for the dehumanising force of monarchic and autocratic regimes of Europe and Russia, going on to refer to the dehumanised condition of members of the African diaspora, Latin American countries and other postcolonial nations reeling under imperial oppression and cultural annihilation (Vaughan, 1988). There has also been equally eloquent criticism on the New Historicist project - that set out to dismantle Shakespeare's camouflaged imperialism and racism - over its selectivity and interpretations through analogies and metaphors (Willis, 1989). Meanwhile, New Historicists like Greenblatt have been criticised for not being radical enough and, by and large, appropriating so-called anecdotal historemes into grand historical discourses (Veenstra, 1995). Simultaneously, there have been influential efforts to recuperate New Historicism as a literary styled archive which brings historiography closer to literary criticism (Laden, 2004). Finally, somewhat ironically, it is Greenblatt who himself writes that although we may choose to see Prospero as Shakespeare himself, what Shakespeare "chooses to do - at least by the standards of Renaissance princes and playwrights alike - is next to nothing. For The Tempest is a play not about possessing absolute power but about giving it up" (2005: 374).

Although not a betrayal of New Historicism, Greenblatt's radically honest admission about Prospero and Shakespeare does go against the more extreme political factions of New Historicist scholars. These contradictions open a gulf between Shakespeareanism (sociological epiphenomena) and Shakespeare (the man himself). At a time when authorial intention is considered irrelevant, asking one to go back to what Shakespeare truly intended in his plays is reductive, besides seemingly fallacious. Various political, racist, imperialist, anticolonial and anti-imperialist symbols of Shakespeareanism are all too wellentrenched by now. We cannot ignore, however, that even by the end of the eighteenth century, Shakespeare was not a recognizably individual author in India, not by the standards of the East India Company, but rather a fragment in a dominant imperial discourse. Indians like Joseph Emin (1919), Mirza Abu Taleb Khan (1810) and Sake Deen Mahomet (1794), who visited England in the 1700s and were deeply influenced by English culture, made no mention of Shakespeare in their accounts, although they acknowledged John Milton and Edmund Burke. Whether or not Shakespeare anticipated imperialist appropriations of Caliban, the genius of The Tempest was covertly exploited by the Company in its mission of civilising Indians, and more overtly by Neill in his recapitulation of Peter's baptism scene from 1616. Although Shakespeareanism gave Woolf the opportunity to invent Judith, examples like those of Catherine challenge such models of Eurocentric feminisms, which, while examining 
histories of gender oppression, tend to overlook their racial aspects. Finally, it is next to impossible to historically evaluate the fragments of John Talbot Shakespear's life as that of a Shakespeare descendant, since his genealogy is overwhelmed and confounded by genealogy of the Thackerays, before being eclipsed by the histories of British Bengal.

Colonial and postcolonial appropriations of Shakespeareanism are both examples of causal or teleological historiography which assume that historical building blocks are geared towards a grand narrative. To see anecdotes as historemes misleads us to think that putting together enough number of them could generate something resembling historical matter, or that history unfolds with a predetermined political and narrative rationale. On the other hand, seeing the anecdotes of Peter, Catherine, Shakespear and even Judith as synchronic fractals, embraces a deeper psychological and narratorial truth. Jung saw synchronicity as a manifestation of the underlying principle of universal unity -Unus Mundus - and of the collective unconscious. Synchronous events are those "'coincidences' which were connected so meaningfully that their 'chance' concurrence would represent a degree of improbability that would have to be expressed by an astronomical figure" (Jung 339). Further, an underlying principle of mathematical unity informed Mandelbrot's definition of fractals as the self-organising and self-duplicating rough edges of natural objects or irregular geometries, that manifested cryptic intelligence in forms of emergent reality. Highly structured anecdotes tend to be appropriated by historical establishmentarianism into anthologies and popular memory, while loose or unstructured ones - such as those in this study — get excluded from authorised histories as irrelevant to contemporary worldviews (Gossman, 2003). If historiography were informed by the insights of Jung and Mandelbrot, the lives of Caliban, Peter, Catherine and Judith-lying between Shakespeare and Shakespear-would appear entangled across space and time. This emergent reality is nothing but a synchronic manifestation of fractal-like behaviour of anecdotes around real or fictional lives. If we compel these anecdotes in causal and teleological history, we end up producing no intelligible discourse but - what may be dismissed by historians across as-Calibanesque gibberish. However, taking the anecdotes of Caliban, Peter, Catherine, Judith, Shakespeare and Shakespear as fractals, we find wilful lacunae in conventional historiographical attempts to incorporate them into established historical frameworks. If New Historicism intended to bridge historiography and the literary, its implicit motive was to expose dominant historical discourses as imprecise approximations. The abject place in history of the actors ranging between Shakespeare and Shakespear reveals that denouncing the approximations and exclusions of imperialist historiography was also based on approximations and exclusions. 
For causal historians, meanwhile, three distinct tasks emerge. A preliminary re-examination of Shakespearean historiography should attempt to trace possible sources behind Woolf's creation of Judith and see if these correlate to histories of black and Indian women in England around Shakespeare's time. One should also attempt to explain the extraordinary coincidence between an Indian spiritually reborn in London as Peter in the year of Shakespeare's death, and his name being invoked over a hundred and fifty years later by an American ecclesiastical historian in Minnesota, only to be recast into oblivion for another century. Finally, if genealogical links do exist between David Cameron and John Talbot Shakespear, as between Shakespear and Shakespeare, antiquarians would do well to establish the line from the bard of Avon to Britain's Brexit Prime Minister, paving the way for explaining what this may mean for Shakespearean history, hermeneutics and literary criticism to come.

\section{WORKS CITED}

Ackroyd, P. London: The Biography. London: Anchor Books, 2003.

Bhattacharyya, S. "Shakespeare and Bengali Theatre." Indian Literature 7.1 (1964): $27-40$.

Brown, P. "“This thing of darkness I acknowledge mine': The Tempest and the discourse of colonialism." In Political Shakespeare: New essays in cultural materialism. Ed. Jonathan Dollimore and Alan Sinfield. Ithaca and London: Cornell University Press, 1985. 48-71.

Burckhardt, S. Shakespearean Meanings. Princeton: Princeton University Press, 1968.

Chatterjee, A.K. Indians in London: From the birth of the East India Company to independent India. New Delhi: Bloomsbury, 2021.

Chatterjee, S. "Mise-en-(Colonial-)Scene: The Theatre of Bengal Renaissance." In Imperialism and Theatre: Essays on World Theatre, Drama, and Performance. Ed. Ellen Gainor. New York and London: Routledge, 1995. 19-36.

Chaudhuri, S. (2005). "Shakespeare's India." In India's Shakespeare: Translation, Interpretation, and Performance. Ed. Poonam Trivedi and Dennis Bartholomeus. Newark: University of Delaware Press, 2005. 151-69.

Comito, T. "Caliban's Dream: The Topography of Some Shakespeare Gardens." Shakespeare Studies 14 (1981): 23-54.

Copland, P. Virginia's God be Thanked: Or, A Sermon of Thanksgiving for the Happie Successe of the Affayres in Virginia. London: W. Sheffard and J. Bellamie, 1622.

Dahiya, H. Essays on Shakespeare: Texts and Contexts. Newcastle upon Tyne: Cambridge Scholars Publishing, 2018.

Dai, Y. "I should like to have my name talked of in China': Charles Lamb, China, and Shakespeare." Multicultural Shakespeare: Translation, Appopriation and Performance 20.1 (2019): 83-97. 
Desai, R.W. "England, the Indian Boy and the Spice Trade in A Midsummer Night's Dream." In India's Shakespeare: Translation, Interpretation, and Performance. Ed. Poonam Trivedi and Dennis Bartholomeus. Newark: University of Delaware Press. 2005. 141-58.

Emin, J. The Life and Adventures. Calcutta: Baptist Mission Press, 1918.

Fineman, J. "The History of the Anecdote: Fiction and Fiction." The New Historicism. Ed. H. Aram Veeser. New York: Routledge, 1989. 49-76.

Fisher, M.H. Counterflows to Colonialism: Indian Travellers and Settlers in Britain, 1600-1857. New Delhi: Permanent Black, 2006.

Flagstad, K. "“Making this Place Paradise': Prospero and the Problem of Caliban in The Tempest." Shakespeare Studies 18 (1986): 205-33.

Foucault, M. The Archaeology of Knowledge. London: Routledge, 2002.

French, George Russell. Shakespeareana Genealogica: Part II. The Shakespeare and Arden Families, and their Connections: with Tables of Descent. London and Cambridge: Macmillan, 1869.

Gossman, L. “Anecdote and History." History and Theory 42.2 (2003): 143-68.

Greenblatt, S. Learning to Curse: Essays in Early Modern Culture. London: Routledge, 1990.

- Shakespearean Negotiations: The Circulation of Social Energy in Renaissance England. Berkeley and Los Angeles: University of California Press, 1988.

Will in The World: How Shakespeare Became Shakespeare. London: Pimlico, 2005.

Habib, I. Black Lives in the English Archives, 1500-1677: Imprints of the Invisible. London: Routledge, 2008.

Jung, C. Essential Jung. Ed. Anthony Storr. Princeton: Princeton University Press, 1999.

Khan, A.T. The Travels of Mirza Abu Taleb Khan in Asia, Africa, and Europe: During the Years 1799 to 1803. Trans. Charles Stewart. London: Longman, Hurst, Rees, and Orme, 1810.

Laden, S. "Recuperating the Archive: Anecdotal Evidence and Questions of 'Historical Realism."” Poetics Today 25.1 (2004): 1-28.

Mahomet, S.D. The Travels of Dean Mahomet. Cork: J. Connor, 1794.

Marcus, L.S. How Shakespeare Became Colonial: Editorial Tradition and the British Empire. Abingdon and New York: Routledge, 2017.

Neill, E.D. Memoir of Rev. Patrick Copland: Rector Elect of the First Projected College in the United States: A Chapter of the English Colonisation of America. New York: Charles Scribner \& Co, 1871.

Neill, S. A History of Christianity in India: The Beginnings to AD 1707. Cambridge: Cambridge University Press, 1984.

Parvini, N. Shakespeare and New Historicist Theory. New York and London: Bloomsbury Academic, 2017.

Sarkar, A. "Shakespeare, Macbeth and the Hindu Nationalism of Nineteenth-Century Bengal." Multicultural Shakespeare: Translation, Appropriation and Performance 13.2 (2016): 117-129.

Shakespeare, W. The Tempest. Collected Works, Vol. 1. Ed. Mr. Theobald. London: Bettesworth, Hitch, Tonson, Wellington, et al, 1733. 1-76. 
Singh, J. Colonial Narratives/Cultural Dialogues: 'Discoveries' of India in the Language of Colonialism. New York and London: Routledge, 1996.

Skura, M.A. "Discourse and the Individual: The Case of Colonialism in The Tempest." Shakespeare Quarterly 40.1 (1989): 42-69.

Taylor, D.B. Fielding's England. London: Dobson, 1967.

Vaughan, A.T. 'Caliban in the 'Third World': Shakespeare's Savage as Sociopolitical Symbol." The Massachusetts Review 29.2 (1988): 289-313.

Veenstra, J.R. "The New Historicism of Stephen Greenblatt: On Poetics of Culture and the Interpretation of Shakespeare." History and Theory 34.3 (1995): 174-98.

Visram, R. Asians in Britain: 400 Years of History. London: Pluto Press, 2002.

Viswanathan, G. Masks of Conquest: Literary Study and British Rule in India. New York and London: Oxford University Press, 1994.

Willis, D. "Shakespeare's Tempest and the Discourse of Colonialism." Studies in English Literature, 1500-1900, 29.2 (1989): 277-289.

Wilson, D. Caliban: The Missing Link. London: Macmillan, 1873.

Woolf, V. A Room of One's Own. London: Hogarth Press, 1935. 